\title{
Effect of intake acidic and alkaline foods to rats before meeting on the probability of offspring gender
}

\section{Tarek M Abd El. Rahman; Khaled A Abd El Rahman and Nglaa A Ebrahim}

Dept. of Nutrition and Food Science, Faculty of Home Economics, Menoufia University, Egypt

\section{ABSTRACT}

his study was designed to investigate the effects of consumption acidic
and alkaline food to determine offspring gender. In total, 20 female
albino rats and 5 males were chosen and randomly divided into 5 groups all groups of rats were fed on the experimental diet. After 20 days of special diet, the female rats were mated with males and were separated after pregnancy. The newborn rats' sexes were determined after delivery. In potatoes group $(58 \%)$ males and $(42 \%)$ female rats were born (sex ratio $=1.38)$ while these rates were $(61 \%)$ male and $(39 \%)$ female $($ sex ratio $=1.56)$ in potatoes plus $\mathrm{K}_{2} \mathrm{HPO}_{4}$ group , in milk group (57\%)male and (43\%) females (Sex ratio $=$ 1.33), in milk plus $\mathrm{CaCO}_{3}(46 \%)$ male and $(54 \%)$ female (Sex ratio $\left.=.85\right)$ while in control group (47\%) male and (53\%) female rats were born (sex ratio = .89). (ALT), and (AST) were determined, Serum creatinine, serum uric acid and serum bilirubin measured. Blood analysis included WBC count, and platelet count (PLC). The present results observed that acidic and alkaline food in the diet of rats can have significant effect on the sex ratio of delivered rats' offspring.

Key words: potatoes, milk, sex ratio, pH, offsprings, Wistar rat. 


\section{INTRODUCTION}

In order to function properly the blood and other body fluids must maintain a very narrow Acid/Alkaline balance (Donald and Hayes; 2012).

One environmental factor vital in the growth and development of the fetus is nutrition (Van et al., 2001). Each food potentially has a different result on the $\mathrm{pH}$ of the body, they are said to be "acidforming" or "alkaline-forming (Donald and Hayes; 2012). Effects of Sodium and Potassium in diet to determine rats baby have been investigated from Chandraju et al ., (2012) and Chandraju et al., (2013) who were found that rats fed with (Na, K) food yields maximum numbers of male offspring 68 , while rats fed with normal food yields lowest numbers of male offspring 48. It has been suggested that the $\mathrm{pH}$ of the vagina at the time of fertilization may have a differential effect on $\mathrm{X}$ - or $\mathrm{Y}$ bearing sperm and thereby affect the sex of the offspring, there are also methods which use different food combinations and especial diets to maximize the chance of having a baby with specific sex (Muehleis and Long, 1976). The diet may influence the conditions within the reproductive tract and the outer barrier surrounding the ovum. Enabling only one of the two types of sperm to penetrate is depending on which diet is adhered (Stolkowskowski and Lorrain, 1982). There are also methods which use different food combinations and especial diets to maximum the chance of having a baby with specific sex (Meikle and Thornton, 1995).

Some studies were based on theories that sperm carrying the $\mathrm{X}$ or $\mathrm{Y}$ chromosome favored different vaginal $\mathrm{pH}$.Therefore, it has been suggested that the $\mathrm{pH}$ of the vagina at the time of fertilization may have 
differential effect on $\mathrm{X}$ - or $\mathrm{Y}$ sperm and thereby affect the sex of the offspring (Muehleis and Long, 1976).

At coitus, human sperm are deposited into the anterior vagina, where, to avoid vaginal acid and immune responses, they quickly contact cervical mucus and enter the cervix. Cervical mucus filters out sperm with poor morphology and motility and as such only aminority of ejaculated sperm actually enter the cervix (Suarez and Pacey, 2006).

\section{Vahidi and Sheikhha,} (2007) suggested that different amount of ions in the diet of rats can have significant effect on the sex ratio of delivered rats' offspring. After a long journey, the spermatozoa meet the oocyte in the specific site of the oviduct named ampulla and fertilization takes place. Avery low percentage of the sperm population is able to reach the ampulla or the ampullar-isthmic (Coy et al., 2012).

\section{Also Najmeh et al.,} (2014) found that: ginger extract alters the function of the reproductive system in male and female rats and increases sex ratio of male and the chance of male birth. It can be concluded that a person who receives food rich in calcium or devoid of sodium, and potassium, serum ratio of ions is affected.

\section{MATERIALS \& METHODS}

\section{Materials:}

Casein, corn oil, vitamins and minerals mixture, were obtained from Morgan Co. Cairo, Egypt according to AIN, 1993 guidelines (Reeves et al., 1993).

Potato: were purchased from local market in Shibin El- kom from the same type and soil, and dried by dryer oven at the laboratory of Home Economic faculty and analyzed it in National research Centre to 
know potassium percent in potatoes and it founded 1.55 $\mathrm{g} / 100 \mathrm{gm}$.

Dry milk Powder: obtained from the El-Huda company and analyzed in National research Centre to know calcium percent in dry milk and it founded 1g/100gm.

K2HPO4 and CaCO3 powders: obtained from NODCAR.

(NODCAR): the national organization for drug control and research).

\section{Methods:}

Experimental design:

Twenty female and five male albino rats, Wistar Strain, (8-10 weeks) age weight (150 $\pm 2 \mathrm{~g}$ ). The animals were derived from research institute ophthalmology medical analysis department in Giza Egypt. Rats were kept in cylindrical wire cages. The diet was introduced in special food cups to avoid scattering of food Also water was provided to the rats by glass tube projection through the wire cage. Food and water were provided adibtium and checked daily.

All rats were divided into five groups in the ratio male to female 1:4 according to (Chandraju et al., 2012) and fed on the experimental diet for 20 days according to the following groups.

Group (1): This group was fed on basal diet only.

Group (2): This group was fed basal diet and $1.5 \%$ potato powder Add to the meal according to Vahidi and Sheikhha, (2007).

Group (3): This group was fed basal diet and $1.5 \%$ potato powder plus $\mathrm{K}_{2} \mathrm{HPO}_{4}(5 \%)$ in water.

Group (4): This group was fed basal diet and .5\% Dry milk Add to the meal (Vahidi and Sheikhha, 2007).

Group (5): This group was fed basal diet and .5\% Dry milk plus $\mathrm{CaCO} 3(5 \%)$ in water. 


$\begin{array}{llr}\text { The animals were } \\ \text { applied } & \text { on institute }\end{array}$
ophthalmology medical analysis department in Giza Egypt. After 20 days of experimental diet males were mated with females and after occurring pregnancy it was separated and after 20- 23 day they gave birth and determined the sex of babies after Weaning. At the end of the experiment rats were fasted overnight (12 hours) and anesthetized with diethyl ether. Blood samples were divided into portion part1 and collected into a dry clean centrifuge glass tubes. Serum was separated by centrifugation at 4000 r.p.m for 15 minutes at room temperature. Serum was carefully aspirated and transferred into clean quiet fit plastic tubes and kept frozen at $\left(-20^{\circ} \mathrm{C}\right)$ until analysis. Part 2 were collected in tube contain ethylene di amine tetra acetic acid (EDTA) to estimate WBC and platelet count.
Biochemical analysis:

Alanine aminotransferase (ALT) and Aspartate amino transferase (AST) were determined according to the methods described by Xing-Jiu et al., (2006). Serum creatinine, serum uric acid and serum Billirubin measured were determined according to the methods described by Sox, (1986). Blood analysis included WBC count, and platelet count (PLC), carried out according to Jacobs et al., (2001).

\section{Statistical Analysis:}

Statistical analysis were performed by IBM-P-C computer hardware compact 1998, under Windows Microsoft Office 2010 using statistical package program for Social Science (SPSS, 2010) and compared with each other using the suitable test. All obtained results were tabulated and suitable recommendation was 
given (Artimage and Berry, 1987).

\section{RESULTS \& DISCUSSION}

\section{A-sex ratio}

It was found that, in the first group (potatoes), all of the 4 rats became pregnant which delivered 38 offspring. Their gender was 22 male $(58 \%)$ and 16 female $(42 \%)$. In the second group, (potatoes $\& \mathrm{~K}_{2} \mathrm{HPO}_{4}$ ), all 4 rats became pregnant and delivered 33 offsprings ,their gender was 20 male (61\%) and 13 female (39\%). in the third group, (milk ) all 4 rats became pregnant and delivered 33 offspring, 19 male (57\%) and 14female $(43 \%)$.and in the fourth group, (milk \& $\mathrm{CaCO}_{3}$ ) all 4 rats became pregnant and delivered 35 offspring, 16male (46\%) and 19 female (54\%).in the control group all rats became pregnant and delivered 34 offspring, 16 male(47\%) and 18 female $(53 \%)$ The sex ratio of male to female was 0.89 , the sex ratio of male to female in the first group of (potatoes) and control group 1.38: 0.89 , in the second group, (potatoes and alkaline solution $\mathrm{K}_{2} \mathrm{HPO}_{4}$ )were $1.56: 0.89$, in the third group (milk) $1.33: 0.89$ and in the fourth group( milk \&CaCO3) were $0.85: 0.89$. The Total no of offspring in the second group mothers (group 2) 38 was higher than offsprings in control group 34(Table1).

It was found that acidic and alkaline food can determine sex ratio on rats according to (Chandraju et al., 2012). our result showed that consumption foods high in potassium can change the $\mathrm{pH}$ of body fluids such as vagina fluid as this mineral have an effect on vaginal $\mathrm{pH}$ and make alkaline vaginal environment so that $\mathrm{Y}$ sperm motility accelerates in this environment and can influence the sex of the fetus Compatible with (Najmeh et al ., 2014). 
And consumption foods high in calcium enhance acidic environment and having female infant, Yet these results are inconsistent with Stolkowski'sreport since he stated that majority of rats receiving a food rich in calcium will give birth to a male infant (Stolkowski, 1977). Overall, we can conclude that the results of the effect of consumption alkaline and acidic food are consistent with the findings of previous researchers, and advocates of sex determination using the diet (Stolkowski and Lorrain, 1980).

\section{B-Biochemical changes:}

Data tabulated in table (2) showed that ALT, AST( U/L), Billirubin, Createnine, Uacid (mg/dl), WBC and PLT( $\mathrm{mm} 3$ ) determined rats fed on basal diet control and basal diet blend with potatoes, potatoes with $\mathrm{K}_{2} \mathrm{HPO}_{4}$, milk and milk with $\mathrm{CaCO}_{3}$ over 20 day. ALT recorded high significant differences $(\mathrm{p} \leq 0.01)$ for potatoes, potatoes \& $\mathrm{K}_{2} \mathrm{HPO}_{4}$ and milk while there was a nonsignificant difference for group Milk \& $\mathrm{CaCO}_{3}$ respectively. AST recorded High significant differences $(\mathrm{p} \leq 0.01)$ for Milk and Milk $\& \mathrm{CaCO}_{3}$ nonsignificant for potatoes and Potatoes \& $\mathrm{K}_{2} \mathrm{HPO}_{4} \quad$ group respectively. Table (2) illustrated the effect of high potassium and calcium diet on liver function of rats, AST and ALT Record increasing for potatoes, potatoes with $\mathrm{K}_{2} \mathrm{HPO}_{4}$ that may happened because of the alkaline environment which enhance liver enzymes according to (Virginia, 1997) Many enzymes and chemical reactions in the body work best at a particular $\mathrm{pH}$ as liver $\mathrm{pH}$ is 7-7.2.

Bilirubin recorded high significant differences $(p \leq 0.01)$ for potatoes and milk group and non-significant for potatoes\& $\mathrm{K}_{2} \mathrm{HPO}_{4}$, Milk \& $\mathrm{CaCO}_{3}$ group respectively. Level of Bilirubin 
in potatoes, potatoes \& $\mathrm{K}_{2} \mathrm{HPO}_{4}$ and Milk group has decreased when compared with control group and this decreasing not refer to desease according to (Agrawal and Rudrani, 2015) Serum bilirubin concentrations in the upper portion of the reference value (0.61$1.0 \mathrm{mg} / \mathrm{dl}$ ) reduce atherogenic risk and provide protection against Coronary artery disease.

Uric acid recorded High significant differences $(\mathrm{p} \leq 0.01)$ for potatoes and milk\&CaCO${ }_{3}$ group and Very high significant differences $(\mathrm{p} \leq 0.001)$ for potatoes with $\mathrm{K}_{2} \mathrm{HPO}_{4}$ group and non-significant differences for milk group respectively. According to (Reddy et al ; 2002). Alow-carbohydrate highprotein diet with its increased acid load results in very little change in blood chemistry, and $\mathrm{pH}$, but results in many changes in urinary chemistry. Urinary magnesium levels, urinary citrate and $\mathrm{pH}$ are decreased, urinary calcium, undissociated uric acid, and phosphate are increased. All of these result in an increased risk for kidney stones. In milk group we found increasing in uric acid than control group and other groups that may be happened because of high amount of milk in diet.

Creatinine recorded nonsignificant differences for all groups. Generally, a high serum creatinine level indicated that your kidneys aren't working well. Creatinine level may temporarily increase if you're dehydrated, have a low blood volume, eat a large amount of meat or take certain medications (John et al., 2004) as what happened in potatoes with $\mathrm{K}_{2} \mathrm{HPO}_{4}$ and milk\&CaCO group because of having $\mathrm{K}_{2} \mathrm{HPO}_{4}$ and $\mathrm{CaCO}_{3}$ solution.

Platelets count and white blood cells, recorded nonsignificant differences for all groups and showed decreasing its number and low immune 
system activity in an acid environment in milk and milk with $\mathrm{CaCo}_{3}$ groups, while it was high in potatoes and potatoes\& $\mathrm{K}_{2} \mathrm{HPO}_{4}$

Abnormalities in systemic acid-base balance may cause significant changes in the immune response agreement with (Tales et al; 2013) and (Anne Lardner, 2001). It has been suggested that an alkaline diet may prevent a number of diseases and result in significant health benefits (Gerry, 2012) .from our results we can say that alkaline diet have more benefits for the body health and immunity .

\section{CONCLUSION}

This study designed to know the effect of consumption the acidic and alkaline food on baby sex and it were conducted some chemical tests to find out the result of the consumption of these foods on the health and safety of the body such as the liver, kidneys and immune system organs.

Present results showed that: Consumption of potatoes high in potassium can change body fluids $\mathrm{pH}$ from acidity to alkalinity and encourages male born and support the immune system and other body organs, and Consumption of milk high in calcium can change body fluids $\mathrm{pH}$ from alkalinity to acidity and encourages female born with no adverse effects on vital values. The acid-alkaline balance is an important factor in the health and functioning of the body and to keep this balance we must increase vegetables and fruit than protein in our diet.

\section{REFERANCES}

Agrawal VV and Rudrani Sh (2015):

To study inverse relationship between serum total bilirubin levels and severity of disease in 
Effect of intake acidic and alkaline foods to rats before meeting on the probability of offspring gender

Tarek, M. Abd El. Rahman, Khaled, A. Abd El.Rahman, Nglaa, A. Ebrahim

patients with stable coronary artery disease as assessed by coronary angiography and syntax score. Journal of Indian College of Cardiology, Volume 5, Issue 3, September 2015, Pages 209-213.

\section{Anne Lardner (2001):}

The effects of extra cellular $\mathrm{pH}$ on immune function. Journal of Leukocyte Biology Volume 69.

\section{Artimage GY and Berry WG} (1987):

Statistical Methods 7th Ed. Ames, Iowa State University Press, 39-63.

\section{Chandraju S; Beirami A and} Chidan KCS (2012):

Role of sodium and potassium ions in identification of offspring gender in rats. IOSR Journal of Pharmacy, Volume 2 Issue 6.
Chandraju S; Beirami A and Chidan KCS (2013):

Impact of sodium and potassium ions in identification of offspring gender in high sugar rabbits 4(1): 21-30.

Coy P; Garcia - Va 'zquez FA; Visconti PE and Avile's M (2012):

Roles of the oviduct in mammalian fertilization . Reproduction 144649-660.

Donald $L$ and Hayes DC (2012):

ALKALIZE NOW - $\mathrm{pH}$ Balance Program 5th Edition, 2012, ISBN: 978-161658-139-8.

\section{Gerry KS (2012):}

The Alkaline Diet: Is There Evidence That an Alkaline pH Diet Benefits Health? J Environ Public Healthv. 2012; PMC3195546. 
Jacobs DS; Oxley DK and Demott WR (2001):

Laboratory Test Handbook.

Lexi-Comp, Inc University of

Ottawa, Ottawa, Ontario, Canada.

John RA; Webbyoung EP; Stevens and Onreferred (2004):

Chronic kidney disease alongitadine am akidny (43): 53-825-35.

\section{Meikle DB and Thornton MW} (1995) :

Premating and gestational effects of maternal nutrition on secondary sex ratio in house mice. J. Reprod.Fertil. 105; 193-196.

\section{Muehleis PM and Long SY} (1976):

Fertility and Sterility 27(12):1438-1445 Type: Journal Article, Comparative Study.
Najmeh FI; Saeid K; Manzarbano Sh; Hossein K and Zahra K (2014):

Effects of administration of hydroalcoholic extract of ginger (Zingiberofficinale) on blood serum cations $(\mathrm{Mg}, \mathrm{Na}$ $+, \mathrm{K}+, \mathrm{Ca} 2+)$ and the sex ratio of male and female newborn Wister rats / J.BIOL.TODAYS WORLD.; 3 (7): 157-161.

\section{Reddy ST; Wang CY; Sakhaee}

K; Brinkley L. and Pak CY (2002):

Effect of low-carbohydrate high-protein diets on acidbase balance, stone-forming propensity, and calcium metabolism. American Journal of Kidney Diseases ; 40(2):265-274.

\section{Reeves PG; Nielsen FH and} Fahey GC (1993):

AIN-93 purified diets for laboratory rodents: final report of the American Institute of Nutrition adhoc 
writing committee on the reformulation of the AIN76 A rodent diet. J. Nutr., 123: 1939-1951.

\section{Sox HC (1986):}

Probability theory in the use of diagnostic test, an introduction to critical study of the literature. Ann. Intern. Med., 104(1): 60-66.

Stolkowski J (1977):

Magnesium in animal and human reproduction. Revue canadienne de biologie / editee par l'Universite de Montreal.;36(2):13577. Epub 1977/ 06/ 01. Le magnesium dans la reproduction animale et chez l'homme.

\section{Stolkowski J and Lorrain J} (1980):

Preconceptional selection of fetal sex International journal of gynecology and obstetrics: the official organ of the International
Federation of Gynaecology and Obstetrics; 18(6):4403.

Stolkowskowski J and Lorrain J (1982):

Reconceptional selection of Fetal Sex.int. J. Gynaecol. Obstet;18: 440-3.

Suarez SS and Pacey AA (2006):

Sperm transport in the female reproductive tract. Human Reproduction Update, Vol.12, No.1 pp. 23-37, 2006 doi: 10.1093 /humupd /dmi 047.

Tales R; Mariane N; Agnes AS; Albuquerque Marco T; Menezes Andrea CC and Paulo RB (2013):

Metabolic Acidosis Treatment as Part of a Strategy to Curb Inflammation. International Journal of Inflammation 
Effect of intake acidic and alkaline foods to rats before meeting on the probability of offspring gender

Tarek, M. Abd El. Rahman, Khaled, A. Abd El.Rahman, Nglaa, A. Ebrahim

Volume (2013), Article ID 601424, 4 pages.

Vahidi AR and Sheikhha MH (2007):

Comparing the Effects of Sodium and Potassium Diet with Calcium and Magnesium Diet on Sex Ratio of Rats' Offspring IPakistan Journal of Nutrition 6 (1): 44-48 ISSN 1680-5194.

\section{Van A; Holemans F and Aerts}

L (2001):

Long-term consequences for offspring of diabetes during pregnancy. British Medi Nal Bulletin.; 60; 173 182 (PMID:12027).
Virginia W (1997):

Acide-Alkaline Balance and your health, Journal Article, copyright price -Pottenger Nutrition Foundation.

Volume 21:4.

Xing-Jiu H; Yang-Kyu Ch; Hyung-Soon I; Oktay Y; Euisik $Y$ and Hak-Sung K (2006):

Aspartate Aminotransferase (AST/GOT) and Alanine Aminotransferase (ALT / GPT) Detection Techniques; Published online 2006 Jul 31. 6(7): 756-782. PMCID: PMC 3894536. 
TABLE 1: Sex ratio in different groups of Wistar rats

\begin{tabular}{|l|l|l|l|l|l|l|}
\hline Groups & $\begin{array}{l}\text { Total no. } \\
\text { of } \\
\text { offspring }\end{array}$ & $\begin{array}{l}\text { No. of } \\
\text { male } \\
\text { offspring }\end{array}$ & $\begin{array}{l}\text { \% age of } \\
\text { male } \\
\text { offspring }\end{array}$ & $\begin{array}{l}\text { No. of } \\
\text { female } \\
\text { offspring }\end{array}$ & $\begin{array}{l}\text { \% age } \\
\text { female } \\
\text { offspring }\end{array}$ & $\begin{array}{l}\text { Sex } \\
\text { ratio }\end{array}$ \\
\hline Control & 34 & 16 & $47 \%$ & 18 & $53 \%$ & $\mathbf{0 . 8 9}$ \\
\hline Potatoes & 38 & 22 & $58 \%$ & 16 & $42 \%$ & $\mathbf{1 . 3 8}$ \\
\hline $\begin{array}{l}\text { Potatoes } \\
\text { \&K} \mathbf{H P O}_{\mathbf{4}}\end{array}$ & 33 & 20 & $61 \%$ & 13 & $39 \%$ & $\mathbf{1 . 5 6}$ \\
\hline Milk & 33 & 19 & $57 \%$ & 14 & $43 \%$ & $\mathbf{1 . 3 3}$ \\
\hline $\begin{array}{l}\text { Milk } \\
\text { \&CaCO }\end{array}$ & 35 & 16 & $46 \%$ & 19 & $54 \%$ & $\mathbf{0 . 8 5}$ \\
\hline
\end{tabular}


Effect of intake acidic and alkaline foods to rats before meeting on the probability of offspring gender

Table (2):Serum ALT, AST( U/L), Billirubin, Createnine, Uric acid (mg/dl), WBC and PLT( mm3) determined rats fed on basal diet control and basal diet blend with potatoes, potatoes with $\mathrm{K}_{2} \mathrm{HPO}_{4}$, milk and milk with $\mathrm{CaCO}_{3}$ over 20 day.

\begin{tabular}{|c|c|c|c|c|c|}
\hline $\begin{array}{l}\text { Category } \\
\text { Statistical }\end{array}$ & Control & Potatoes & $\begin{array}{l}\text { Potatoes } \\
\text { \& K2HPO4 }\end{array}$ & Milk & Milk \&CaCO3 \\
\hline \multicolumn{6}{|l|}{ Mean \pm SD } \\
\hline AST U/L & $154.00 \pm 9.79$ & $159.00 \pm 1.63$ & $157.00 \pm 10.20$ & $182.00 \pm 10.61 * *$ & $123.00 \pm 13.47 * *$ \\
\hline ALT U/L & $47.00 \pm 8.98$ & $66.00 \pm 5.71^{* *}$ & $68.00 \pm 8.98 * *$ & $63.00 \pm .40^{* * *}$ & $41.5 \pm 3.67$ \\
\hline Billirubin mg/dl & $0.87 \pm .04$ & $.69 \pm .06^{* *}$ & $.76 \pm .09$ & $.71 \pm .05 * *$ & $.89 \pm .02$ \\
\hline Createnine mg/dl & $0.58 \pm .04$ & $.57 \pm .02$ & $.59 \pm .01$ & $.55 \pm .02$ & $.61 \pm .04$ \\
\hline Uric acid mg/dl & $3.40 \pm .20$ & $3.71 \pm .41 * *$ & $2.45 \pm .16$ & $3.98 \pm 1.35^{* * *}$ & $3.06 \pm .78 * *$ \\
\hline WBC mm3 & $11.48 \pm 5.32$ & $10.23 \pm 8.68$ & $10.03 \pm 6.15$ & $8.10 \pm .57$ & $9.75 \pm 8.85$ \\
\hline PLT mm3 & $563.25 \pm 74.27$ & $589.25 \pm 163.84$ & $480.75 \pm 72.99$ & $524.75 \pm 101.58$ & $517.75 \pm 81.71$ \\
\hline
\end{tabular}




\section{تأثير تناول الأغذية الحامضية والقلوية على الجرذان قبل

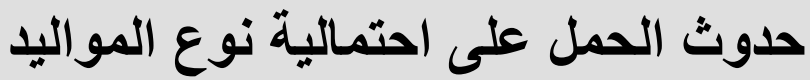

طارق محمد عبد الرحمن عفيفي و خالد علي عبد الرحمن شاهين ونجلاء

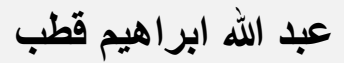

قسم التغذية وعلوم الاطعمة ـ كلية الاقتصاد المنزلي - جامعة المنوفية

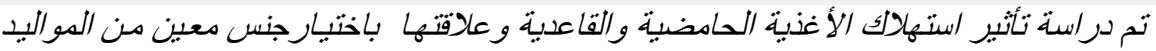

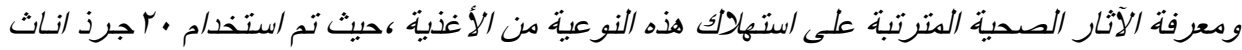

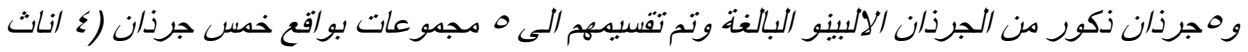

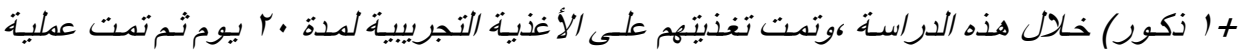

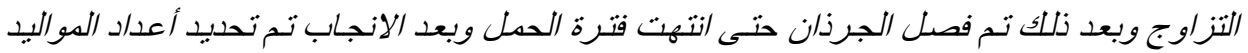

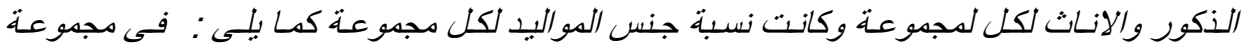

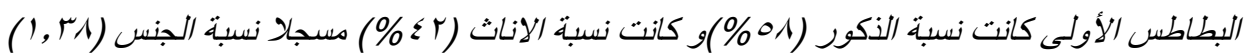
، أمسا فسى مجدوعة البطاطس المضساف اليها محلول

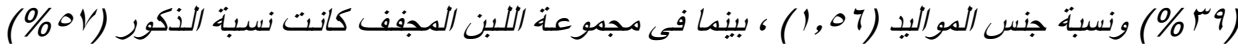

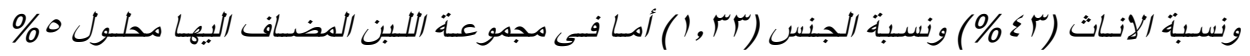

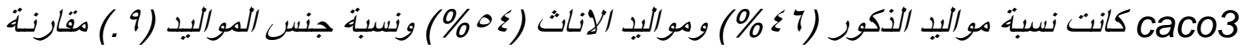

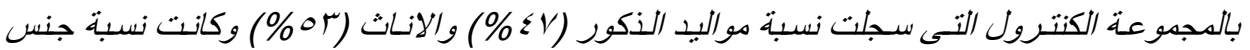

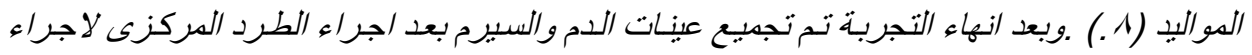
(ALT,AST ,BILLIRUBIN , CREATININE , WBC and PLATELETES). تحليل وأوضحت النتائج التى تم الحصول عليها أن استهلاك الأغنية الحامضية والعالبية فحى محتواها من

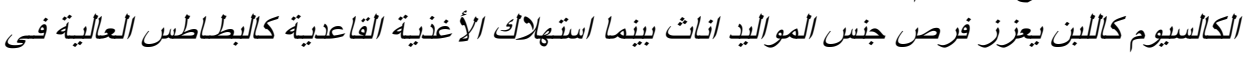

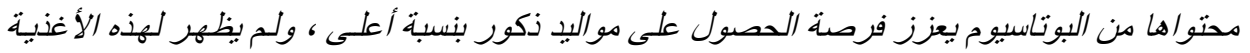

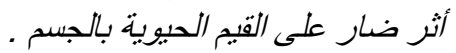

الكلمات المفتاحية: البطاطس - اللبن ـالنسبة بين الجنسين- ودرجة الحموضة- النسلالجرذان. 